\title{
Characterization of Kono-Boue Clay as Possible Catalyst for Biodiesel Production
}

\author{
Gbarakoro, S. L. ${ }^{1,2}$, Konne, J.L. ${ }^{2}$, Boisa, N. ${ }^{2}$ \\ ${ }^{1}$ Department of Science Laboratory Technology, School of Applied Sciences, Ken Saro-Wiwa Polytechnic, Bori, Rivers State, Nigeria \\ ${ }^{2}$ Department of Chemistry, Faculty of Science, Rivers State University of Science and Technology, Nkpolu-Oroworukwo, Port Harcourt, \\ Nigeria
}

\begin{abstract}
The Kono-Boue clay in Rivers State, Nigeria, which is currently applied locally for pottery, building bricks, and as medicine, had been characterized to determine its mineral structure using X-ray crystallography. Its surface morphology and elemental composition were determined using scanning electron microscopy (SEM) and energy dispersive $X$-ray (EDX) respectively. The $X$-ray crystallography identified the clay as aluminium silicate with similar structure as kaolinite, which matched with berlinite crystal

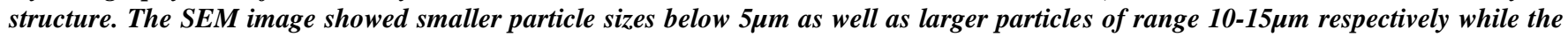
EDX result showed $\sim 50 \%$ counts of Si/Al (ratio of 4:1); $\sim 40 \%$ for $O, S, M g, K$, and Fe while the remaining $\sim 10 \%$ were shared by Ti, $\mathrm{Zr}, \mathrm{W}, \mathrm{Hg}$ and $\mathrm{Au}$.
\end{abstract}

Keywords: Kono Boue Clay, XRD, SEM, Catalyst, Characterisation, and Biodiesel.

\section{Introduction}

The inevitability of global warming, the greenhouse effects and criticisms of fossil fuels for their depletion, environmental hazards and lack of sustainability have put many researchers to study in biodiesel production as a viable and promising alternative energy source [1,2]. Presently, both homogeneous and heterogeneous catalysts are being employed to catalyze transesterification reaction for biodiesel productions. Homogeneous catalysts used include some acids and bases such as tetraoxosulphate (VI) acid, phosphoric acid, etc and sodium hydroxide, potassium hydroxide, etc., respectively [3]. However, these have been found to be expensive and environmentally unfriendly. On the other hand, heterogeneous catalysts such as zeolites or clays have the advantage of easy separation from products over the homogeneous and the spent catalysts also ecofriendly.

Clays are natural, earthy, fine-grained materials, $<2 \mu \mathrm{m}$, which develop plasticity when mixed with a limited quantity of water and harden when dried or fired [4]. Clays are collectively called alumino-silicates. This is because the universal minerals contained mainly aluminium and silicon oxides while water often with iron, alkaline and alkaline earth metals are minor components [5]. Clays have special features to be used as catalysts. These features include availability, versatility, selectivity, low cost as well as ease of use and preparation. Besides, it possessed bronsted-lowry basic and acidic sites, porosity and ability to be pillared with exchangeable cations amongst others. Clay catalysts are environmentally benign, recyclable and economical. Therefore both natural as well as numerous modified forms are used as good catalyst for transesterification in biodiesel synthesis and diverse chemical reactions [6].

Biodiesel is one of the pioneering forms of alternative energy. It is a renewable, highly biodegradable, non-toxic and environmentally friendly bioenergy, which can be utilized in engines without any modification $[1,7,8,9]$.
Many clay catalysts have been characterized and studied for the production of biodiesel in recent times. For example, the use of some Brazillian natural clays (smectite, atapulgite and vermicu-lite), without pre-treatment or activation, was demonstrated by Silva and coworkers [10] to act as good catalysts for transesterification of ethyl acetoacetate and ethyl benzoylacetate by six carbohydrate acetonides. In a related study, acid activated Indian bentonite was shown to be a good catalyst, in some cases better than zeolites, for the preparation of aryl and alkyl esters of fourteen different aromatic and aliphatic carboxylic acids [11]. Similarly, Villegas and Coworkers characterized natural Brazillian clays such as F-101 clay, a smectite, F-117, which has an interstratified structure with smectite, kaoline and mica as clay minerals and kaoline and used them as catalysts in the co-iodination reactions of styrene and cyclohexene with water and alcohol [12]. Gao and $\mathrm{Xu}$ reported Clay as catalyst support where they used vanadium oxide catalyst supported on clay (chlorite, illite, and atapulgite from inner Mongolia) for the oxidation of benzene to phenol using hydrogen peroxide as co-oxidant [13]. The use of natural zeolite - supported on $\mathrm{KOH}$ has also been reported as heterogeneous catalyst or catalyst supports in biodiesel production [14].

Ojo and others investigated the sedimentological and geochemical studies of Maastrichtian clays in Bida basin of Nigeria. The results obtained from the physical and geochemical features confirmed it to be kaolinitic clay and could be utilized as catalysts, amongst other industrial purposes [15]. Montmorillonite clay from Udi in Nigeria has also been acid-activated and used as a catalyst in liguidphase esterification of acetic acid with ethanol [16]. Clay obtained from Suleja and Shabu, Nigeria has also been used as catalyst for the esterification of propan-1-ol with propanoic acid [17].

Although, other researchers have investigated and characterized clay obtained from other parts of the country as catalysts for biodiesel production, there is no report on the characterization of Kono-Boue clay. Therefore, this research

Volume 5 Issue 6, June 2016 www.ijsr.net 


\section{International Journal of Science and Research (IJSR) \\ ISSN (Online): 2319-7064}

Index Copernicus Value (2013): 6.14 | Impact Factor (2015): 6.391

seeks to characterize Kono-Boue clay using techniques like powder x-ray diffraction (PXRD), to confirm its mineral structure; scanning electron microscopy (SEM), its surface morphology and energy dispersive X-ray for its elemental composition and other relevant properties. The study will help to mitigate the environmental effect of the currently used catalysts $(\mathrm{NaOH}$ or $\mathrm{HCl})$ with a re-useable solid catalyst. The success of this will provide a new source of cheap and easily available heterogeneous catalyst for our local industries and the world at large.

\section{Materials and Methods}

Map of Ogoniland Showing sampling town of KONO BOUE, www.unep.org/nigeria.

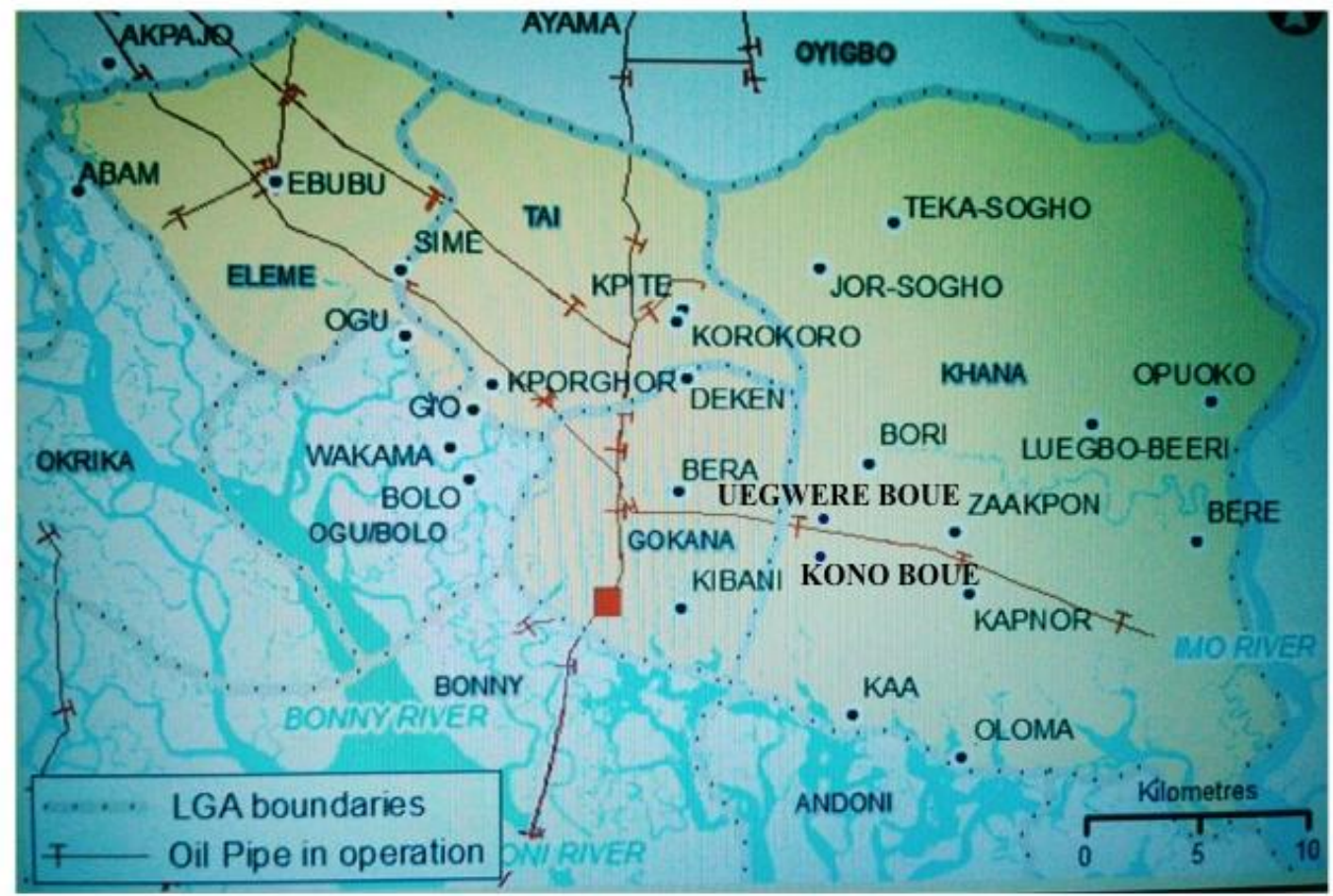

- KONO BOUE (Latitude $4^{\circ} 42^{\prime} \mathrm{N}$, Longitude $7^{\circ} 22^{\prime} \mathrm{E}$ )

Figure 1: Map of Ogoniland showing Kono Boue Town (courtesy, July 2011 UNEP Report).

\subsection{Methods}

\subsubsection{Clay collection and preparation}

The raw clay sample was dug and collected from a clay mine at Kono-Boue town, Rivers State Nigeria, manually with a shovel at a depth of about $50 \mathrm{~cm}$, and placed in a clean polythene bag. The clay sample was then oven dried at $110^{\circ} \mathrm{C}$ for 4 hours to ensure complete evaporation of the moisture content. The dried clay was milled and sieved through a British Standard Sieve (BSS) 100mm mesh.

\subsubsection{Characterization of clay}

The dried, milled clay sample was characterized to determine its mineral structure using X-ray diffraction (XRD) on an EMMA GBC diffractometer at the NASENI centre, Akure, Ondo, Nigeria. The instrument used the monochromatic $\mathrm{CuK} \alpha 1$ radiation source. The settings used included scan angles of $2 \theta, 20-70^{\circ}$ with step size of 0.05 and dwell time of $0.025 \mathrm{~s}$. The SEM was ASPEX 3020 model equipped with an Oxford EDX detector.

\subsection{Materials}

Kono-Boue clay was taken from Kono-Boue town situated on Latitude $4^{\circ} 42^{\prime}$ North of the equator and Longitude $7^{\circ}$ 22' East of Greenwich meridian in the Khana Local Government Area of Rivers State, Nigeria (See Figure 1 below for the location of Kono Boue Town in Ogoni land of Nigeria). Other materials used include weighing balance, British Standard Sieve (BSS) $100 \mathrm{~mm}$ mesh, oven, pot, spatula, mortar and pestle.

\section{Results and Discussion}

\subsection{X-ray Diffraction (XRD)}

The major x-ray reflections of Kono-Boue clay matched with berlinite $\left(\mathrm{AlPO}_{4}\right)$ crystal structure. The pattern was indexed to the Joint Committee on Powder Diffraction and Standards (JCPDS) file number, 003-0447 (Figure 2) while the 2-theta angles, d-spacing and relative intensities are shown in Table 1. The major peaks as labeled also matched with Kaolinite clay phase as reported in literature [5]. Therefore it was necessary to confirm its elemental composition using energy dispersive X-ray (EDX) analysis.

Volume 5 Issue 6, June 2016 www.ijsr.net 


\section{International Journal of Science and Research (IJSR) \\ ISSN (Online): 2319-7064}

Index Copernicus Value (2013): 6.14 | Impact Factor (2015): 6.391

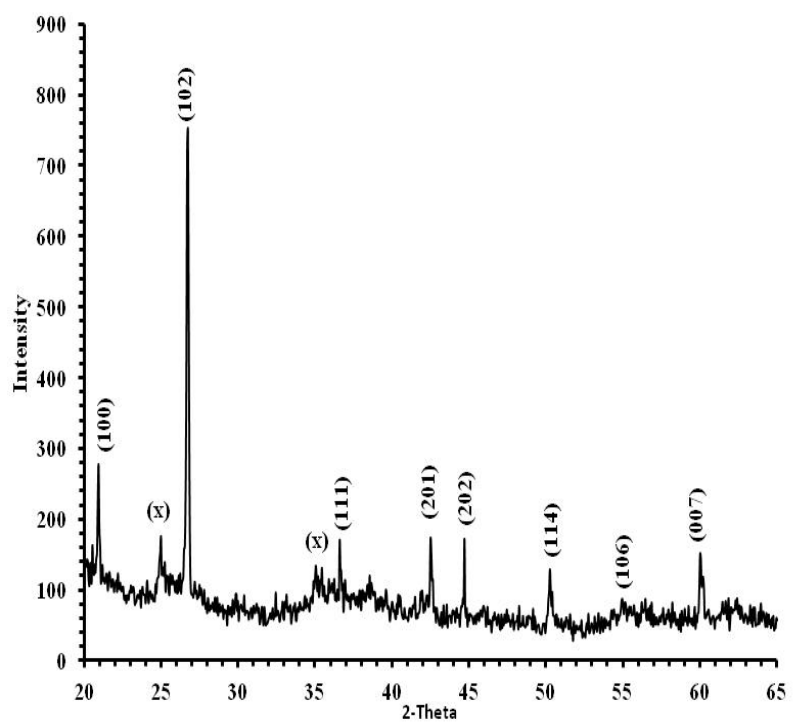

Figure 2: XRD analysis of Kono-Boue Clay showing reflections of Aluminium Silicate (Clay) which crystallized with $\mathrm{AlPO}_{4}$ Crystal Structure (JCPDS file number: $003-$ 0447). $X=$ Minor oxide phases.

Table 1: Showing the d-spacing, relative intensities and hkl of Kono Boue clay powder

\begin{tabular}{|c|c|r|c|}
\hline 2-Theta & $d(\AA)$ & Intensity & $h k l$ \\
\hline 21.0344 & 4.22 & 66 & 100 \\
\hline 26.8311 & 3.32 & 100 & 102 \\
\hline 36.8048 & 2.44 & 52 & 111 \\
\hline 39.4909 & 2.28 & 56 & 104 \\
\hline 42.6109 & 2.12 & 45 & 201 \\
\hline 45.7884 & 1.98 & 29 & 202 \\
\hline 50.0775 & 1.82 & 86 & 114 \\
\hline 54.9350 & 1.67 & 53 & 106 \\
\hline 60.0241 & 1.54 & 75 & 007 \\
\hline 63.6854 & 1.46 & 23 & 116 \\
\hline 67.8592 & 1.38 & 96 & 206 \\
\hline
\end{tabular}

The EDX (Figure 3) showed absence of Phosphorus and as such Kono Boue clay would not contain $\mathrm{AlPO}_{4}$ rather it should be aluminium silicates (Kaolinite) due to its composition. Kaolinite minerals, $\mathrm{Al}_{2} \mathrm{Si}_{2} \mathrm{O}_{5}(\mathrm{OH})_{4}$ or $\mathrm{Al}_{2} \mathrm{O}_{3} \cdot 2 \mathrm{SiO}_{2} \cdot 2 \mathrm{H}_{2} \mathrm{O}$ consist of silica (tetrahedral) and aluminium (octahedral) sheets separated by small singly and doubly charged metals like $\mathrm{K}, \mathrm{Mg}$ and Fe [5]. However, Kono Boue clay also contained S. Peaks of only the major elements appeared on the EDX spectrum of Figure 3 while the data sheet contained all of them (See Table 2 for the elemental compositions).

Table 2: Elemental composition of Kono-Boue clay as analyzed by EDX

\begin{tabular}{|c|c|}
\hline Elements & Counts \\
\hline $\mathrm{Al}$ & 10.0 \\
\hline $\mathrm{Si}$ & 41.4 \\
\hline $\mathrm{S}$ & 1.0 \\
\hline $\mathrm{K}$ & 3.3 \\
\hline $\mathrm{Mg}$ & 3.3 \\
\hline $\mathrm{Fe}$ & 3.9 \\
\hline $\mathrm{O}$ & 30.8 \\
\hline $\mathrm{Ti}$ & 1.3 \\
\hline $\mathrm{Zr}$ & 1.7 \\
\hline $\mathrm{W}$ & 2.7 \\
\hline $\mathrm{Hg}$ & 2.2 \\
\hline $\mathrm{Au}$ & 1.7 \\
\hline
\end{tabular}

The presence of other important elements like $\mathrm{Ti}, \mathrm{Zr}, \mathrm{W}, \mathrm{Hg}$ and $\mathrm{Au}$ in Kono Boue clay would enhance its catalytic activity and commercial value. The result also indicates the possibility of larger occurrence of these elements in other minerals around the same geographical location. This report would also inform the users of the clay for medicinal purposes presence of the presence of toxic elements like mercury in Kono Boue clay.

\subsection{Energy Dispersive X-ray (EDX)}

The EDX spectrum showed counts of major components with Silicon being the highest (Figure 3) followed by oxygen and aluminium while others were of approximately the same count rate. This EDX result confirmed that KonoBoue clay is of the alumino-silicate (Kaolinite) type clay. Kono-Boue clay like any other naturally occurring clay such as kaolinite, hectorite and montmorillonite, have layer structures of octahedral and tetrahedral units. Aluminum occupies the octahedral site while silicon, the tetrahedral site. The crystal structure of Kono Boue clay compared closely with other clays found in Nigeria.

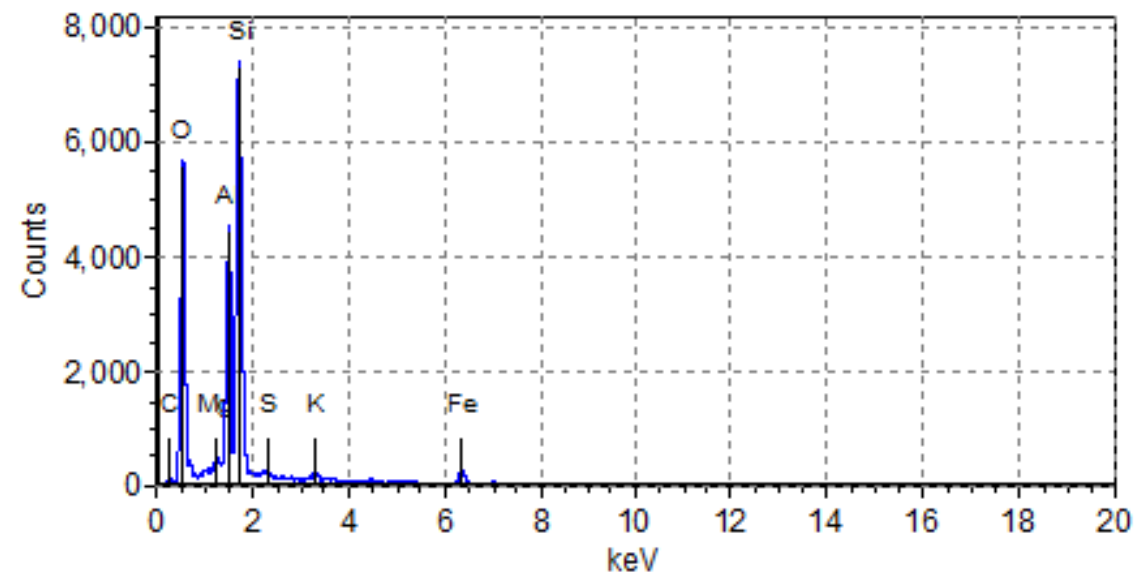

Figure 3: EDX spectrum of Kono-Boue Clay showing counts of major components ( $\mathrm{Si}, \mathrm{O}, \mathrm{Al}, \mathrm{etc})$ 


\section{International Journal of Science and Research (IJSR) \\ ISSN (Online): 2319-7064}

Index Copernicus Value (2013): 6.14 | Impact Factor (2015): 6.391

Forinstance, the Ibere and Oboro clay deposits in Abia State, a neighbouring State to Rivers State in Nigeria are largely kaolinite, chemically composed of mainly silica $(52.06 \%$ and $60.21 \%$ respectively) and alumina $(27.87 \%$ and $19.05 \%$ respectively) [18]. In a related study of sedimentological and geochemical characteristics of Maastrichtian clay in Bida Basin Nigeria, geochemical data showed that the clay stone at Share composed of $\mathrm{SiO}_{2}$ ranging from $45.2 \%$ to $64.8 \%$ (average of 58.1\%) while at Agbeja, the values ranged from $48.5 \%$ to $74.7 \%$ (average of $63.3 \%$ ) [15]. The $\mathrm{Al}_{2} \mathrm{O}_{3}$ value for the clay at Share ranged from $20.3 \%$ to $37.9 \%$ (averaging $26.9 \%$ ) while, the Agbeja samples was between $15.61 \%$ and $34.23 \%$ with an average of $24.6 \%$. The findings indicated that the clays were essentially hydrated siliceous aluminosilicates. Similar high percentage of $\mathrm{SiO}_{2}$ (F-101, 66.19\%; F-117, 59.57\% and kaoline, 53.09\%) and low percentage of $\mathrm{Al}_{2} \mathrm{O}_{3}$ (F-101, 17.0\%; F-117, 22.28\% and kaoline, $42.47 \%$ ) was reported for Brazilian clay [12].

\subsection{Scanning Electron Microscopy (SEM)}

The surface morphology of Kono-Boue clay was studied by using the SEM technique. The SEM micrograph shown in Figure 4 showed varying distribution of aggregate crystallites. The smaller particle sizes were largely below $5 \mu \mathrm{m}$ while the larger ones were of the $10-15 \mu \mathrm{m}$ ranges, respectively. Thus indicating non-uniformity and inherent porosity. This could offer or act as micro catalytic sites or channels when applied as catalysts.

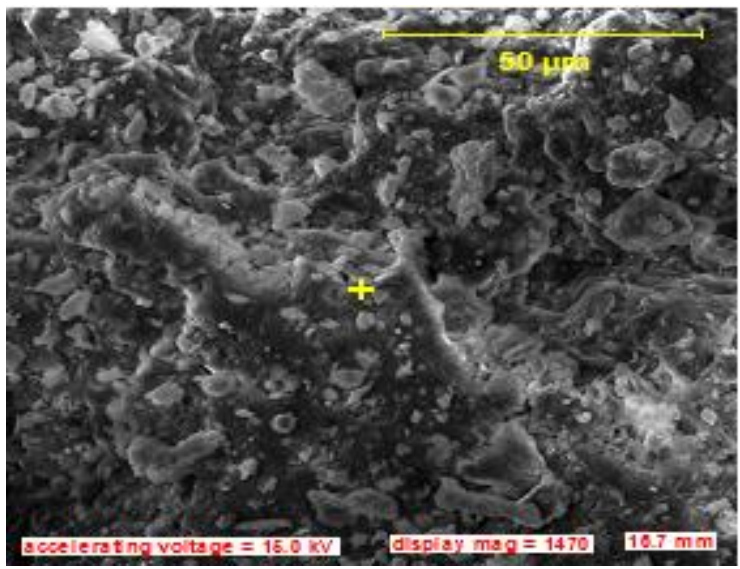

Figure 4: SEM image showing surface morphology of Kono-Boue Clay

\section{Conclusion}

The characterization of Kono-Boue clay using XRD has been reported for the first time. The reflections matched those of $\mathrm{AlPO}_{4}$ and Kaolinite crystal structures. However, the EDX analysis confirmed that it consists largely of Kaolinite clay structure with silicon to aluminum ratio of $4: 1$. The EDX spectrum also indicated the presence of $S$, $\mathrm{Mg}, \mathrm{K}$, and $\mathrm{Fe}$. Other elements found on the EDX analysis data included those of $\mathrm{Ti}, \mathrm{Zr}, \mathrm{W}, \mathrm{Hg}$ and Au. Therefore Kono-Boue clay with the aluminum silicate structure mixed with the above listed elements would be a promising zeolite or clay catalyst for biodiesel production and heterogeneous catalysis in general.

\section{References}

[1] Saifuddin, M. , Goh, P.E. , Ho, W.S., Moneruzzaman, K.M. and Fatima, A. (2014). Biodiesel production from waste cooking palm oil and Environmental Impact Analysis. Bulgarian Journal of Agricultural Science, 20(1); 186-192.

[2] Irmawati, R., Shafizah, I. . Sharina, A.N., Ahangar,H.A. and Taufiq-Yap, Y.H. (2014).Trans esterification of Palm Oil by using Silica loaded Potassium Carbonate $\left(\mathrm{K}_{2} \mathrm{CO}_{3} / \mathrm{SiO}_{2}\right)$ Catalysts to produce Fatty Acid Methyl Esters (FAME), Energy and Power, 4(1): 7-15.

[3] Marwan, Suhendrayatna and Indarti, E. (2015). Preparation of Biodiesel from Microalgae and Palm Oil by Direct Transesterification in a Batch Microwave Reactor. Journal of Physics Conference Series 622 (012040): 1-8.

[4] Guggenheim, S. and Martin, R.T. (1995). Definition of clay and clay Mineral Joint Report of the AIPEA Nomenclature and CMS Nomenclature Committees. Clay and Clay Minerals, 43: 25-256

[5] Mukasa - Tebandeke, I.Z., Ssebuwufu, P.J.M., Nyanzi, S. A., Schumann, A., Nyakairu, G.W.A., Ntale, M. and Lugolobi, F. (2015). The elemental, mineralogical, IR, DTA and XRD Analysis Characterized Clays and Clay Minerals of Central and Eastern Uganda. Advances in material Physics and chemistry, 5, 67-86

[6] Nagendrappa, G. (2010). Organic Synthesis using clay and Clay-Supported Catalysts. Journal of Applied Clay Science, 51:106-138, Bangalore, India.

[7] Narasimharao, K., Lee, A., and Wilson, K., (2007). "Catalysis in Production of Biodiesels", Journal Biodiesel Mat. Bioenergy, 1: 19-30.

[8] Lee, D., Park, Y., and Lee, K. (2009). Heterogeneous Base Catalysts for Transesterification in Biodiesel Synthesis. Catal Surv Asia, 13; 63-77

[9] Tazerout, M., Ndayishimiye, P. and Masimala, S.K. (2009). "Performance and emission studies on a CI engine using methyl esters of palm oil and waste cooking oil mixture as fuel". New Frontiers in Biofuels, Scitech Publications (India), 154-161.

[10] Silva, F.C., desouza, M.C.B.V., Ferreira, V.F., Sabino, S.J., and Antuned, O.A.C., (2004). Natural clays as Efficient Catalysts for obtaining Chiral $\beta$ Enaminoesters. Catal. Communi. 5:151-155.

[11] Vijayakumar, B., Iyengar, P., Nagendrappa, G., JaiPrakash, B.S., (2004). A Facile Synthesis of Fatty Acid Esters of P-Cresol Catalyzed by Acid Activated Indian Bentonite. Indian Journal Chem. Technol 11: 565-568.

[12] Villegas, R.A.S., Santo, J.L.E., Mattos, M.C.S., Aguiar, M.R.M.P. and Guarino, A.W.S. (2005). Characterisation of Natural Brazilian Clays and their Utilization as catalysts in the Coiodination of alkenes with water and alcohols. Journal of Brazilian chemical society. 16: $565-570$.

[13] Gao, X., and Xu, J., (2006). A New Application of Clay-Supported Variation Oxide Catalyst to Selective Hydroxylation of Benzene to Phenol. Appl. Clay Sci. 33:1-6.

[14] Kusuma, R I., Hadinoto, J. P., and Ismadji, S. (2013). Natural zeolite from Pacitan Indonesia, as catalyst support for transesterification of palm oil. Applied Clay Science, 74: 121-126. 


\section{International Journal of Science and Research (IJSR) \\ ISSN (Online): 2319-7064}

Index Copernicus Value (2013): 6.14 | Impact Factor (2015): 6.391

[15] Ojo, O. J., Adepoju, S. A. Ademole, T. M. and Abiola, A. O. (2011). Sedimatological and Geochemical studies of Maastrichain clays in Bido, Basin, Nigeria; implication for resource potential. Centrepoint Journal (Science edition), 17(2); 71-88

[16] Igbokwe, P.K. and Olebunne, F.L. (2011). Catalytic Esterification of Acetic Acid with Ethanol using Nigerian Montmorillonite Clay: Effect of Reaction Variables on Catalyst Efficiency. Journal of the University of Chemical Technology and Metallurgy, 46, 4, 389-394.

[17]Dim, P.E., Okafor, J.O., Edoga, M.O. and Onukwuli, O.D. (2013). Nigerian clay as a Catalyst for Esterification of Propan-1-ol with Propanoic acid. Research Journal of Engineering Sciences, 2(2), 7-10.

[18] Mark, U. (2010) Characterization of Ibere and Oboro Clay Deposits in Abia State, Nigeria for refractory applications. International Journal of Natural and Applied Sciences, 6(3):296-365.

[19] United Nations Environment Programme (UNEP) Report. (2011). www.unep.org/nigeria.

Volume 5 Issue 6, June 2016 www.ijsr.net 